\title{
PENGARUH IBU HAMIL PEROKOK PASIF TERHADAP KEJADIAN LAHIR MATI DI KOTA AMBON
}

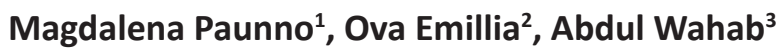

\begin{abstract}
Background: Intervention in the care for pregnant women can reduce antenatal mortality until $75 \%$. Antenatal Care (ANC) in Ambon municipality is categorized good if compared from the mean rate of national level, that is, Visit 1 (89\%) and Visit 4 (87.76\%); however, the incidence of stillbirths in Ambon is still considered high. Data about the incidence of stillbirths in three hospitals of Ambon showed that there were 44.2 stillbirths per 1000 live births while national data in 2003 showed that there were only 9.6 stillbirths per 1000 live births. The direct cause of stillbirth is hypoxia, that is, the lack of oxygen in a pregnant woman's body due to the exposure of cigarette smoke. In Ambon municipality, $65 \%$ of households have 1 active smoker and almost all of the smokers (90\%) smoke inside the house. This rate of course exceeds the national rate. In addition, other factors causing stillbirth are the quality of antenatal care, age, parity, anemia and women's educational level.

Objective: To study whether passive smoking during pregnancy is a risk factor of the incidence of stillbirths. Method: This was an observational study with case-control study design. Study sites were in three hospitals of Ambon municipality, namely Dr. M. Haulussy District Hospital, Al-Fatah Hospital, and Sumber Hidup Hospital. Subjects were divided into two groups which were case and control with comparison of 1:1 (69 stillbirths as case and 69 live births as control) from January to December 2007. Samples were taken using non probability sampling which was determined with quota sample. The analysis of quantitative data used univariable analysis, bivariable analysis with chi-square test $\left(\chi^{2}\right)$ and stratification, and multivariable analysis with logistic regression.
\end{abstract}

Result and Discussion: There was a significant relationship between passive smoking during pregnancy and the incidence of stillbirth based on bivariable analysis with $\mathrm{OR}=3.36(95 \% \mathrm{Cl}=1.20-5.41)$ while based on multivariable analysis with $\mathrm{OR}=2.8$ (1.01-7.94). Other risk factors that affected the incidence of stillbirth were the quality of antenatal care with $\mathrm{OR}=3.2(95 \% \mathrm{Cl}=1.39-7.52)$ and anemia during pregnancy with $\mathrm{OR}=2.3$ (95\% $\mathrm{Cl}=1.20-5.41)$. Meanwhile, stratification analysis showed that non anemic women during pregnancy was significantly related to stillbirths with $\mathrm{OR}=5.7$ ( $95 \% \mathrm{Cl} 1.10-55.22)$. However, age, parity and education were not the risk factors of the incidence of stillbirth in Ambon.

Conclusion: Passive smoking during pregnancy was a risk factor of the incidence of stillbirth in Ambon municipality. Other factors that caused the incidence of stillbirths were the quality of antenatal care and anemia. However, age, and parity were not the risk factors of the incidence of stillbirths in Ambon.

Keywords: pregnant woman, passive smoking, stillbirth

Air Selobar Community Health Center, Ambon Health Office, Maluku Province

Obstetric and Gynecology Division, Faculty of Medicine,

Gadjah Mada University, Yogyakarta

3 Maternal and Child Health-Reproductive Health, Graduate Program,

Faculty of Medicine, Gadjah Mada University, Yogyakarta 


\section{INTISARI}

Latar belakang: Intervensi pada perawatan ibu hamil dapat menurunkan kematian perinatal hingga 75\%. ANC di Kota Ambon dikategorikan baik, bila dilihat angka rata-rata secara nasional yaitu K1 89\%, K4 87,76\% namun, kejadian lahir mati sangat tinggi dibanding angka nasional. Salah satu penyebab langsung lahir mati adalah hypokxia yaitu kekurangan oksigen dalam tubuh ibu, akibat dari ibu hamil terpapar asap rokok. Di Kota Ambon, 65\% rumah tangga mempunyai 1 orang perokok, dan hampir semua perokok (90\%) merokok di rumah. Angka ini lebih tinggi dari angka nasional. Faktor lain menyebabkan lahir mati adalah kualitas antenatal care, umur, paritas anemia ibu selama hamil, pendidikan ibu yang rendah.

Tujuan: Penelitian ini untuk mengetahui apakah ibu hamil perokok pasif merupakan faktor risiko kejadian lahir mati.

Metode: Penelitian observasional dengan rancangan kasus-kontrol. Lokasi penelitian pada 3 RS di Kota Ambon yaitu: RSUD dr. M. Haulussy, RS. Al-Fatah, RS. Sumber Hidup. Subjek penelitian 1:1 69 lahir mati (kasus) dan 69 lahir hidup (kontrol) pada bulan Januari sampai dengan bulan Desember 2007. Pengambilan sampel dengan cara non probability sampling, ditentukan secara quota sample. Analisis data terdiri dari analisis univariabel, analisis bivariabel menggunakan uji chi-square $\left(\chi^{2}\right)$, stratifikasi serta analisis multivariabel menggunakan regresi logistik.

Hasil dan Pembahasan: Ada hubungan yang bermakna antara ibu hamil perokok pasif dengan kejadian lahir mati. Analisis bivariabel $\mathrm{OR}=3,36(95 \% \mathrm{Cl}=1,20-5,41)$ analisis multivariabel $\mathrm{OR}=2,8(1,01-7,94)$. Faktor risiko lain yang mempengaruhi kejadian lahir mati adalah: Kualitas antenatal care mempunyai nilai $\mathrm{OR}=3,2$ $(95 \% \mathrm{Cl}=1,39-7,52)$, ibu hamil anemia $\mathrm{OR}=2,3(95 \% \mathrm{Cl}=1,20-5,41)$ dan pendidikan $\mathrm{OR}=2,42(1,15-5,10)$. Saat analisis strativikasi, ibu tidak anemia mempunyai hubungan bermakna dengan lahir mati OR=5,7 (95\% $\mathrm{Cl}$ 1,10-55,22). Umur, paritas dan pendidikan bukan merupakan faktor risiko lahir mati di Kota Ambon.

Kesimpulan : Ibu hamil perokok pasif merupakan faktor risiko terhadap kejadian lahir mati di Kota Ambon. Faktor lain yang menyebabkan lahir mati adalah kualitas antenatal care dan anemia ibu hamil.

Kata kunci: ibu hamil, perokok pasif, lahir mati.

\section{PENDAHULUAN}

Lahir mati merupakan penyumbang angka kematian bayi di negara maju maupun di negaranegara berkembang, termasuk di Indonesia. Kelangsungan hidup bayi sangat ditentukan oleh kondisi pertumbuhan janin di dalam uterus. Salah satu penyebab mortalitas pada masa janin disebabkan karena adanya gangguan oksigenasi. Menurut Goldenberg (2004) gangguan oksigenasi pada masa janin salah satunya akibat paparan asap rokok selama ibu hamil.

Nikotin, CO dalam asap rokok terbukti merusak endotel (dinding pembuluh darah), dan mempermudah timbulnya penggumpalan darah, sehingga menyumbat pembuluh darah termasuk di tali pusat dan di plasenta. ${ }^{1,8}$ Kelangsungan suatu kehamilan sangat bergantung pada keadaan dan kesehatan ibu, plasenta dan keadaan janin. ${ }^{27,8,25}$

Prevalensi perokok pasif cenderung mengalami peningkatan seiring dengan peningkatan prevalensi perokok. Di Indonesia, lebih separuh (57\%) rumah tangga mempunyai sedikitnya satu orang perokok, dan hampir semua perokok $(91,8 \%)$ merokok di rumah. Di Kota Ambon, 65\% rumah tangga mempunyai 1 orang perokok, dan hampir semua perokok (90\%) merokok di rumah. $^{7}$

Di Kota Ambon kualitas ANC dikategorikan baik, bila dilihat angka rata-rata secara nasional yaitu K1 89\%, K4 87,76\%, pertolongan persalinan 
oleh tenaga kesehatan 97\%. Namun angka bayi lahir mati di Kota Ambon tinggi sebesar 44,2 per 1.000 lahir hidup dibandingkan dengan data SDKI 2003 yaitu sebesar 9,6 per 1.000 lahir hidup. Intervensi perawatan ibu hamil (ANC) dapat menurunkan kematian perinatal hingga $75 \%{ }^{12}$. Perawatan secara medis yang teratur terhadap janin dan ibu selama hamil merupakan faktor penting untuk menghindari kelahiran bayi mati ${ }^{25}$, namun terdapat faktor lain yang saling berinteraksi mempengaruhi kualitas janin. ${ }^{6}$ Faktor tersebut meliputi: a) Karakteristik ibu, b) Faktor pelayanan kesehatan yaitu manajemen dan keterampilan memberi pelayanan yang masih kurang, c) Faktor sosial ekonomi, d) Tempat tinggal di dataran tinggi, e) Karakteristik janin ${ }^{18,26,17}$, f) Ibu hamil minum minuman beralkohol, obat-obatan, bahan-bahan toksik, g) Depresi berat, faktor psikologis seperti kekerasan terhadap ibu hamil ${ }^{6}$, paparan asap dapur (biomas) selama hamil. ${ }^{16}$

Penelitian ini memfokuskan pada pengaruh ibu hamil perokok pasif terhadap kejadian lahir mati. Perokok aktif yang dimaksud adalah ada yang merokok di dalam rumah. Efek buruk rokok dalam penelitian ini dikhususkan pada karbon monoksida (CO) dan nikotin. Faktor lain adalah kualitas ANC, umur ibu, paritas, anemia selama hamil, dan pendidikan ibu.

Paparan asap rokok selama wanita hamil menyebabkan efek buruk pada ibu hamil, terutama terhadap janin berupa gangguan fungsi tali pusat dan plasenta. Berdasar latar belakang masalah di atas, maka dapat dirumuskan permasalahan penelitian adalah "Seberapa besar risiko lahir mati pada kelompok ibu hamil perokok pasif dibanding kelompok ibu hamil yang bukan perokok pasif".

\section{METODE}

Jenis penelitian observasional dengan rancangan kasus-kontrol. Dalam penelitian ini sebagai kasus adalah lahir mati dan paparan asap rokok di lingkungan rumah (perokok pasif). Subjek dalam penelitian ini adalah semua ibu yang melahirkan bayi lahir hidup dan lahir mati di 3 RS terbesar di Kota Ambon tahun 2007 yaitu: RSUD dr. M. Haulussy, RS. Al-Fatah, RS. Sumber Hidup. Waktu penelitian bulan Oktober sampai dengan bulan November 2008

Semua subjek penelitian harus memenuhi kriteria inklusi dan eksklusi seperti tersebut di bawah ini. Kriteria inklusi adalah: a) Umur kehamilan saat persalinan 28 minggu sampai 40 minggu, b) Bayi mengalami intra uterine fetal death (IUFD), c) Bertempat tinggal tetap di Kota Ambon dan saat pengambilan data ibu berada di Kota Ambon. Kriteria eksklusi adalah: a) Ibu menderita penyakit hipertensi dan penyakit diabetes mellitus, b) Perokok tidak menetap di rumah selama ibu hamil, c) Ibu perokok aktif, d) Janin dengan kelainan kongenital.

Perhitungan besar sampel kasus kontrol tanpa matching dengan mempertimbangkan penelitian sebelumnya dengan sampel minimal yang diteliti untuk kasus kontrol 1:1 adalah 69:69 sehingga jumlah sampel total adalah 138 orang. ${ }^{17}$ Cara pengambilan sampel yaitu dengan cara non probability sampling, ditentukan secara quota sample.

Variabel yang terdapat dalam penelitian ini adalah variabel tergantung yaitu lahir mati, variabel bebas adalah ibu hamil perokok pasif dan variabel luar adalah kualitas ANC, umur, paritas, anemia dan pendidikan ibu.

Data yang digunakan dalam penelitian ini berupa data sekunder yang diperoleh dari kuesioner meliputi identitas, sosiodemografi dan data obstetri yang bersumber dari buku KIA. Data primer mengenai perokok pasif ditanyakan langsung ke ibu. Sedangkan data variabel terikat yaitu lahir mati atau IUFD menurut diagnosis dokter di catatan medik RS. Data variabel luar yang terdiri dari; kualitas ANC, umur ibu, paritas, anemia, pendidikan ibu, melalui buku ibu hamil atau KMS ibu hamil. 
Analisis data meliputi analisis univariabel, uji Chi-square $\left(\mathrm{c}^{2}\right)$, analisis stratifikasi menggunakan Uji Chi-Square Mantel Haenszel dan analisis multivariabel digunakan untuk mengetahui hubungan variabel bebas dengan variabel terikat secara bersama-sama dengan mengontrol variabel luar.

\section{HASIL DAN PEMBAHASAN}

\section{A. Hasil \\ 1. Karakteristik responden}

Tabel 1 menunjukkan distribusi karakteristik responden pada kelompok lahir mati dan lahir hidup.

Tabel 1. Distribusi Karakteristik Responden Kelompok lahir mati dan kelompok lahir hidup di RSUD dr. M. Haulussy, RS. Al-Fatah, RS. Sumber Hidup Kota Ambon.

\begin{tabular}{|c|c|c|c|c|c|c|}
\hline \multirow[t]{2}{*}{ Karakteristik responden } & \multicolumn{2}{|c|}{ Lahir mati } & \multicolumn{2}{|c|}{ Lahir hidup } & \multirow{2}{*}{$\begin{array}{l}\text { Total } \\
\mathrm{N}=138\end{array}$} & \multirow[b]{2}{*}{$\%$} \\
\hline & $N=69$ & $\%$ & $N=69$ & $\%$ & & \\
\hline \multicolumn{7}{|l|}{ Umur ibu } \\
\hline $\begin{array}{l}\text { - Berisiko, }<20 \text { tahun } \\
\text { dan }>35 \text { tahun }\end{array}$ & 17 & 24.6 & 20 & 29 & 37 & 26,8 \\
\hline $\begin{array}{l}\text { - Tidak berisiko, umur ibu } \\
\text { 20-35 tahun. }\end{array}$ & 52 & 75,4 & 49 & 71 & 101 & 73,2 \\
\hline \multicolumn{7}{|l|}{ Paritas } \\
\hline $\begin{array}{l}\text { - Berisiko, paritas } 1 \text { dan } \\
\text { } \geq 5\end{array}$ & 22 & 31,9 & 13 & 18,8 & 35 & 25,4 \\
\hline $\begin{array}{l}\text { - Tidak berisiko paritas } \\
2-4\end{array}$ & 47 & 68,1 & 56 & 81,2 & 103 & 74,6 \\
\hline \multicolumn{7}{|l|}{ Pendidikan ibu } \\
\hline - Rendah & 44 & 63,8 & 29 & 42,0 & 73 & 52,9 \\
\hline - Tinggi & 25 & 36,2 & 40 & 58,0 & 65 & 47,1 \\
\hline \multicolumn{7}{|l|}{ Ibu hamil perokok } \\
\hline - Perokok pasif & 62 & 89,9 & 50 & 72,5 & 112 & 81,2 \\
\hline - Bukan perokok pasif & 7 & 10,1 & 19 & 27,5 & 26 & 18,8 \\
\hline \multicolumn{7}{|l|}{ Kualitas antenatal care } \\
\hline - Tidak berkualitas & 57 & 82,6 & 40 & 58,0 & 97 & 70,3 \\
\hline - Berkualitas & 12 & 17,4 & 29 & 42,0 & 41 & 29,7 \\
\hline \multicolumn{7}{|l|}{ Status anemia } \\
\hline - Anemia, Hb ibu < 11gr\% & 45 & 65,2 & 25 & 36,2 & 70 & 50,7 \\
\hline $\begin{array}{l}\text { - Tidak anemia, Hb ibu } \\
\quad \geq 11 \text { gr\% }\end{array}$ & 24 & 34,8 & 44 & 63,8 & 68 & 49,3 \\
\hline
\end{tabular}

Mayoritas umur dan paritas ibu tidak berisiko. Di kelompok lahir mati lebih besar pendidikan ibu rendah, ANC tidak berkualitas dan lebih banyak ibu yang anemia. Pada kelompok lahir mati lebih besar ibu hamil perokok pasif dibanding bukan perokok pasif.

\section{Faktor-faktor yang berhubungan dengan lahir mati}

Tabel 2 menunjukkan bahwa faktor ibu perokok pasif, kualitas ANC yang buruk, anemia dan tingkat pendidikan ibu rendah berhubungan dengan kejadian lahir mati. Ibu hamil perokok pasif 3,36 lebih besar mengalami lahir mati dibanding ibu hamil bukan perokok pasif. Kualitas ANC yang buruk meningkatkan lahir mati 3,44 kali dibanding ibu dengan kualitas ANC baik. 
Tabel 2. Hubungan ibu hamil perokok pasif dan kualitas antenatal care, umur ibu, paritas, anemia, pendidikan terhadap lahir mati.

\begin{tabular}{|c|c|c|c|c|c|c|}
\hline Variabel & $\begin{array}{l}\text { Lahir } \\
\text { mati }\end{array}$ & $\begin{array}{l}\text { Lahir } \\
\text { hidup }\end{array}$ & $\chi^{2}$ & $p$ & OR & $95 \% \mathrm{Cl}$ \\
\hline \multicolumn{7}{|l|}{ Ibu hamil perokok } \\
\hline - Perokok pasif & 62 & 50 & 5,73 & $0,00 *$ & 3,36 & $1,22-10,17$ \\
\hline - Bukan perokok pasif & 7 & 19 & & & & \\
\hline \multicolumn{7}{|l|}{ Kualitas antenatal care } \\
\hline - Tidak berkualitas & 57 & 40 & 8,88 & $0,00 *$ & 3,44 & $1,47-8,28$ \\
\hline - Berkualitas & 12 & 29 & & & & \\
\hline \multicolumn{7}{|l|}{ Umur ibu } \\
\hline $\begin{array}{l}\text { - Berisiko, umur ibu }<20 \\
\text { tahun dan }>35 \text { tahun }\end{array}$ & 17 & 20 & 0,15 & 0,56 & 0,31 & $0,35-1,82$ \\
\hline $\begin{array}{l}\text { - Tidak berisiko, umur ibu 20- } \\
35 \text { tahun. }\end{array}$ & 52 & 49 & & & & \\
\hline \multicolumn{7}{|l|}{ Paritas } \\
\hline - Berisiko, paritas 1 dan $\geq 5$ & 22 & 13 & 2,01 & 0,07 & 2,01 & $0,85-4,84$ \\
\hline - Tidak berisiko paritas 2-4 & 47 & 56 & & & & \\
\hline \multicolumn{7}{|l|}{ Status anemia } \\
\hline - Anemia Hb ibu, < 11gr\% & 45 & 25 & 10,47 & $0,00 *$ & 3,30 & $1,55-7,04$ \\
\hline $\begin{array}{l}\text { - Tidak anemia, Hb ibu } \geq 11 \\
\text { gr\% }\end{array}$ & 24 & 44 & & & & \\
\hline \multicolumn{7}{|l|}{ Tingkat pendidikan ibu } \\
\hline - Rendah & 44 & 31 & 5,70 & $0,01^{*}$ & 2,42 & $1,15-5,10$ \\
\hline - Tinggi & 25 & 40 & & & & \\
\hline
\end{tabular}

\section{Keterangan:}

$\chi^{2}(1) \quad$ : Chi Square dengan derajad bebas 1

$\mathrm{P} \quad$ : $P$ Value

OR : Odds Ratio

$95 \% \mathrm{Cl} \quad$ : $95 \%$ Confidence Interval

* : Signifikan

Ibu yang mengalami anemia cenderung mengalami lahir mati 3,30 kali lebih besar dibanding kelompok ibu tanpa anemia. Sedangkan pendidikan ibu yang rendah akan meningkatkan kejadian lahir mati 2,42 kali lebih besar dibanding kelompok ibu dengan pendidikan tinggi. Faktor umur ibu, dan paritas tidak berhubungan dengan lahir mati.
Untuk mengontrol variabel luar yang mungkin berpengaruh maka dilakukan analisis stratifikasi dengan cara mengevaluasi hubungan ibu hamil perokok pasif dengan lahir mati secara terpisah pada masing-masing variabel ANC, anemia, pendidikan (tabel 3). 
Tabel 3. Stratifikasi kualitas ANC, anemia, pendidikan dan ibu hamil perokok pasif dengan kejadian lahir mati

\begin{tabular}{|c|c|c|c|c|c|c|}
\hline Variabel & $\begin{array}{c}\text { Status ibu hamil } \\
\text { perokok }\end{array}$ & $\begin{array}{l}\text { Lahir } \\
\text { Mati }\end{array}$ & $\begin{array}{l}\text { Lahir } \\
\text { Hidup }\end{array}$ & $\begin{array}{c}\text { OR } \\
(95 \% \text { IC) } \\
\end{array}$ & OR-MH & $\begin{array}{c}\text { OR } \\
\text { Crude }\end{array}$ \\
\hline \multicolumn{7}{|l|}{ Antenatal care } \\
\hline \multirow[t]{2}{*}{ Tidak berkualitas } & Perokok pasif & 50 & 32 & 1,7 & 3,17 & 3,36 \\
\hline & Bukan perokok pasif & 7 & 8 & $(0,50-6,37)$ & & \\
\hline \multirow[t]{2}{*}{ Berkualitas } & Perokok pasif & 12 & 18 & & & \\
\hline & Bukan perokok pasif & 0 & 11 & - & & \\
\hline \multicolumn{7}{|l|}{ Status anemia } \\
\hline \multirow[t]{2}{*}{ - Anemia } & Perokok pasif & 40 & 21 & 1,5 & 3,03 & 3,36 \\
\hline & Bukan perokok pasif & 5 & 4 & $(0,27-7,89)$ & & \\
\hline \multirow[t]{2}{*}{ - Tidak anemia } & Perokok pasif & 22 & 29 & 5,7 & & \\
\hline & Bukan perokok pasif & 2 & 15 & $(1,10-55,22)$ & & \\
\hline \multicolumn{7}{|l|}{ Pendidikan } \\
\hline \multirow[t]{2}{*}{ - Rendah } & Perokok pasif & 37 & 24 & 1,5 & 3,66 & 3,36 \\
\hline & Bukan perokok pasif & 7 & 7 & $(0,40-5,85)$ & & \\
\hline \multirow[t]{2}{*}{ - Tinggi } & Perokok pasif & 25 & 26 & & & \\
\hline & Bukan perokok pasif & 0 & 12 & - & & \\
\hline
\end{tabular}

Tabel 3 menunjukkan ibu dengan ANC tidak berkualitas maupun berkualitas dan ibu yang pendidikan rendah maupun pendidikan tinggi tidak berhubungan dengan lahir mati. Sedangkan ibu hamil yang tidak anemia mempunyai hubungan yang bermakna dengan lahir mati. Perubahan nilai OR menunjukan adanya interaksi akibat modifikasi antar variabel. Namun anemia bukan merupakan variabel pengganggu hubungan ibu hamil perokok pasif dengan lahir mati.

\section{Analisis multivariabel}

Analisis multivariabel digunakan untuk mengetahui hubungan variabel bebas (ibu hamil perokok pasif) dengan variabel terikat (lahir mati) secara bersama-sama dengan mengontrol variabel luar (kualitas ANC, anemia dan pendidikan). Uji hipotesis yang digunakan adalah uji regresi logistik dengan tingkat kemaknaan $\mathrm{p}<0,05$ dan 95\% Confidence Interval. Uji stratifikasi antara variabel bebas (ibu hamil perokok pasif) dengan variabel terikat (lahir mati) ketika dianalisis secara bersama-sama dengan mengontrol variabel luar (kualitas ANC, anemia ibu dan pendidikan ibu) hasilnya tetap bermakna (tabel 4).

Tabel 4. Perkiraan Odds Ratio (OR) analisis multivariabel ibu hamil perokok pasif, kualitas ANC, ibu hamil anemia dan pendidikan ibu dengan kejadian lahir mati.

\begin{tabular}{|c|c|c|}
\hline Variabel & OR & $(95 \% \mathrm{Cl})$ \\
\hline $\begin{array}{l}\text { Ibu hamil perokok } \\
\text { - Perokok pasif } \\
\text { - Bukan perokok } \\
\text { pasif }\end{array}$ & 2,8 & $(1,01-7,94)$ \\
\hline $\begin{array}{l}\text { Kualitas ANC } \\
\text { - Tidak berkualitas } \\
\text { - Berkualitas }\end{array}$ & 3,2 & $(1,39-7,52)$ \\
\hline $\begin{array}{l}\text { Anemia } \\
\text { - Anemia } \\
\text { - Tidak anemia }\end{array}$ & 2,5 & $(1,20-5,41)$ \\
\hline $\begin{array}{l}\text { Pendidikan } \\
\text { - Rendah } \\
\text { - Tinggi } \\
\end{array}$ & 1,9 & $(0,92.4,22)$ \\
\hline$R^{2}$ & & 0,14 \\
\hline $\mathrm{N}$ & & 138 \\
\hline
\end{tabular}


Pada kelompok lahir mati lebih besar 2,8 kali ibu hamil perokok pasif dibandingkan kelompok lahir hidup. Kelompok lahir mati lebih besar 3,2 kali ibu yang ANC tidak berkualitas dibandingkan ibu yang ANC berkualitas dan kelompok lahir mati lebih besar 2,5 ibu anemia dibandingkan ibu yang tidak anemia. Sedangkan kelompok lahir mati lebih besar 1,9 kali ibu berpendidikan rendah dibandingkan pendidikan tinggi. Nilai $\mathrm{R}^{2}$ saat uji multivariabel ini dapat disimpulkan bahwa variabel kualitas ANC, anemia dan pendidikan sangat tinggi memberikan kontribusi yaitu sebesar $14 \%$ dalam memprediksi lahir mati.

\section{Pembahasan}

\section{Hubungan ibu hamil perokok pasif dengan kejadian lahir mati.}

Ibu hamil perokok pasif tetap merupakan faktor risiko terhadap kejadian lahir mati. Hal ini dibuktikan melalui hasil uji analisis bivariabel maupun analisis multivariabel.

Hasil penelitian ini mendukung penelitian ${ }^{9}$ yang menyatakan bahwa ibu hamil yang tidak terpapar rokok pasif melahirkan bayi lahir mati lebih kecil, kualitas hidup dan masa hidup lebih panjang jika dibandingkan dengan ibu hamil yang terpapar rokok pasif.

Ojembarrena et al. memaparkan bahwa pada keluarga perokok akan menyebabkan bayi lahir bermasalah yaitu umur kehamilan di bawah berat rata-rata, plasenta abrupsi dan kematian janin intrauteri. ${ }^{21}$ Berdasarkan hasil penelitian ini, nilai OR justru lebih besar dari hasil penelitian lainnya di mana hubungan ibu hamil perokok pasif dengan lahir mati setelah mengendalikan variabel kualitas ANC, anemia dan pendidikan. 17,33 Hasil analisis menunjukkan bahwa variabel kualitas ANC, anemia dan pendidikan lebih besar memprediksi lahir mati (14\%) dan mempunyai hubungan lebih kuat terbukti $O R=2,8$. Hasil penelitian ini didukung oleh Mishra et al. dalam penelitian mengatakan asap rokok ketika dianalisi bersama variabel lain termasuk umur, paritas, perawatan selama hamil, anemia, BMI, tetap bermakna, tetapi hanya dapat memprediksi lahir mati sebesar 1,6 persen. ${ }^{17}$ Penelitian lain mengatakan perokok pasif ketika di analisis bersama variabel luar lain seperti paritas, jenis kelamin, usia ibu, pendidikan, pekerjaan dan berat badan, hasil tetap tidak berubah yaitu ibu yang terpapar asap rokok selama hamil sampai melahirkan berisiko lahir mati 2 kali lebih besar dari ibu yang selama hamil tidak terpapar asap rokok. ${ }^{33}$

Nikotin dan CO yang terisap oleh ibu hamil melalui asap rokok menyebabkan pembuluh darah di tali pusat dan di plasenta mengecil. ${ }^{12,30}$ Hal ini dapat mengurangi jumlah aliran darah, oksigen dan nutrisi untuk janin. Hal ini disebabkan karena perpindahan $\mathrm{O} 2$ dari maternal ke $\mathrm{Hb}$ janin diatur oleh tekanan $\mathrm{O} 2$ dalam pembuluh dadah umbilikus. Dampak lain adalah plasenta menjadi tipis sehingga berisiko lepas sebelum waktunya, risiko kematian bayi lahir mati pun sangat besar.

\section{Hubungan ibu hamil anemia dan tidak anemia dengan kejadian lahir mati.}

WHO menetapkan anemia dalam 3 kategori, yaitu normal ( $\geq 11 \mathrm{gr} / \mathrm{dl})$, anemia ringan (8-11 $\mathrm{g} / \mathrm{dl}$ ), dan anemia berat (kurang dari $8 \mathrm{~g} / \mathrm{dl}$ ). ${ }^{34}$ Berdasarkan hasil pemeriksaan darah ternyata rata-rata kadar hemoglobin ibu hamil adalah sebesar $11.28 \mathrm{mg} / \mathrm{dl}$, kadar hemoglobin terendah $7.63 \mathrm{mg} / \mathrm{dl}$ dan tertinggi $14.00 \mathrm{mg} / \mathrm{dl}^{3}{ }^{3}$

\section{a. Hubungan ibu hamil anemia dengan kejadian lahir mati}

Antara 24 dan 67\% wanita hamil di dunia menderita anemia. Anemia diperkirakan ikut berperan pada hampir $40 \%$ kematian ibu hamil dan memberi kotribusi tinggi untuk kematian perinatal. ${ }^{34}$

Anemia gizi merupakan salah satu dari empat masalah gizi utama di Indonesia. Anemia 
gizi dapat timbul karena kekurangan salah satu atau beberapa zat gizi yang diperlukan untuk pembentukan hemoglobin seperti antara lain besi dan asam folat. Pemberian suplemen asam folat bersamaan dengan suplemen besi karena, efek dari asam folat adalah untuk efektifitas obsorbsi zat besi dalam tubuh. Namun paparan asap rokok yang terlalu tinggi pada perokok pasif akan menurunkan kadar asam folat dalam tubuhnya sehinggga perokok pasif lebih mungkin memiliki tingkat asam folat yang rendah. ${ }^{14}$

Ibu hamil anemia dengan kejadian lahir mati diperoleh hubungan yang signifikan pada hasil uji analisis bivariat maupun multivariat. Namun ketika dianalisis stratifikasi, ditemukan bahwa ibu hamil yang tidak anemia justru mempunyai hubungan yang bermakna dengan lahir mati.

Eritrosit mengandung $\mathrm{Hb}$ dan mengedarkan oksigen/berfungsi sebagai pengikat oksigen. ${ }^{3}$ Orang yang kekurangan eritrosit menderita penyakit anemia yang di tandai dengan $\mathrm{Hb}$ yang rendah. Kadar $\mathrm{Hb}$ ibu hamil yang rendah dapat mengakibatkan gangguan tranportasi oksigen dan nutrisi dari ibu ke janin, yang dapat mengakibatkan hambatan pertumbuhan janin.

Ada keterkaitan positif antara hematokrit yang rendah dan kelahiran preterm pada wanita berkulit hitam, dan menyarankan bahwa anemia merupakan menyebabkan hambatan pertumbuhan janin. ${ }^{15}$ Anemia dapat menyebabkan penyakit kardiovaskular. Bukti bahwa anemia ibu mempengaruhi vaskularisasi plasenta dengan mengubah pertumbuhan pembuluh darah dalam embrio (angiogenesis) pada awal kehamilan.

\section{b. Hubungan ibu hamil tidak anemia dengan kejadian lahir mati}

Kadar $\mathrm{Hb}$ yang tinggi tidak menjamin kualitas janin baik. ${ }^{28} \mathrm{Hal}$ yang sama ditemui dalam penelitian ini bahwa kelompok lahir mati terjadi 5,7 kali lebih besar pada ibu hamil perokok pasif yang tidak anemia. Selanjutnya bila pengidap anemia memiliki $\mathrm{Hb}$ kurang dari normal, maka dalam sel darah merah pengidap polisitenia (kebanyakan sel darah merah) kadar Hb-nya lebih dari 20 gram per desiliter. Secara umum, jenis polisitenia terbagi dua, yakni polisitenia vera (primer) dan sekunder. Polisitemia primer lebih disebabkan faktor keturunan (genetik), sedangkan jenis sekunder dipicu kebiasaan merokok dan tidak terbukti disebabkan faktor makanan.

Kadar CO yang tinggi tidak disangkal lagi dapat mengakibatkan kematian janin. ${ }^{20}$ Diketahui bahwa CO dan nikotin saling berinteraksi mengakibatkan terjadi pengentalan darah. Pengentalan darah ini sangat mempengaruhi kadar $\mathrm{Hb}$. Orang yang terpapar asap rokok mepunyai kadar $\mathrm{Hb}$ yang lebih tinggi dari pada orang yang tidak terpapar asap rokok. Selanjutnya dikatakan bahwa bila mau mencegah, berhentilah merokok. ${ }^{28}$

Kelangsungan suatu kehamilan sangat bergantung pada keadaan dan kesehatan ibu, plasenta dan keadaan janin. ${ }^{27}$ Kadar $\mathrm{Hb}$ yang tinggi ditambah jumlah hematokrit di atas 52akan membuat kondisi darah mengental dan menggumpal (hiperkoagulasi). ${ }^{28}$ Akibatnya, kerja jantung memompa darah ke seluruh tubuh terpaksa menjadi lebih berat risiko gangguan defuse oksigen ke jaringan tubuh ibu terlebih ke janin. Nikotin dan CO yang terisap oleh ibu hamil menyebabkan pembuluh darah di plasenta mengecil. ${ }^{25} \mathrm{Hal}$ ini dapat mengurangi jumlah aliran darah, oksigen dan nutrisi untuk janin. Dampak lain adalah plasenta menjadi tipis, sehingga berisiko lepas sebelum waktunya, risiko kematian bayi lahir mati juga sangat besar.

Penelitian kasus kontrol dengan metode meta analisis menunjukkan bahwa adanya trombofillia akan meningkatkan risiko bayi lahir mati dengan rasio probabilitas 3,$6 ; 95 \% \mathrm{Cl}$ 1,49,4. ${ }^{8}$ Trombofillia ini dipengaruhi oleh sistem 
vaskuler darah seperti gumpalan darah di pembuluh darah menyebabkan trombosis yang berhubungan dengan polisitemia.

Konsentrasi $\mathrm{Hb}<$ atau $=11,5 \mathrm{gd} / \mathrm{I}$ mempunyai OR 1,2 tetapi tidak signifikan terhadap kejadian lahir mati, justru konsentrasi $\mathrm{Hb} \geq 14,6 \mathrm{~g} / \mathrm{dl}$ pada awal dan akhir kehamilan meningkatkan risiko lahir mati 1,8 kali. ${ }^{26}$ Di negara-negara dunia ketiga ironisnya, pada wanita yang sebenarnya sehat di mana konsentrasi hemoglobin lebih tinggi cenderung menyebabkan gangguan hasil kehamilan. ${ }^{30}$ Secara spesifik, wanita yang konsentrasi hemoglobinnya lebih dari 13,2 g/ dl minggu memperlihatkan peningkatan angka kematian perinatal. Hemoglobin yang rendah $<<$ 3 SD) pada gestasi 12 minggu yang menyebabkan resiko 1,7 kali lipat untuk kelahiran preterm, sedangkan hemoglobin yang tinggi (> $3 \mathrm{SD}$ ) pada gestasi 12 sampai 18 minggu memperlihatkan peningkatan 1,3 sampai 1,8 kali lipat untuk hambatan pertumbuhan janin selanjutnya akan memperbesar bayi lahir mati.

Selain merokok, penduduk yang tinggal di kawasan dataran tinggi (lebih dari 3.000 meter di atas permukaan laut) memiliki ancaman lebih besar terkena polisitenia karena kadar oksigennya tipis. ${ }^{28}$ Untuk memenuhi kebutuhan oksigen, maka di dalam tubuh manusia terdapat suatu sistem kesetimbangan yang berperan dalam menjaga fungsi fisiologis tubuh untuk beradaptasi dengan lingkungannya, sehingga rata-rata penduduk yang bertempat tinggal di dataran tinggi akan memiliki $\mathrm{Hb}$ lebih tinggi daripada penduduk yang bertempat tinggal di dataran rendah.

Data Dinas Kesehatan Kota Ambon khusus tentang hasil pengukuran kadar $\mathrm{Hb}$ ibu hamil dikategori lebih banyak ibu hamil tidak anemia. Angka kejadian ibu hamil anemia sangat rendah $(2,21 \%)$ sehingga, kemungkinan dapat dicurigai bahwa ada kemungkinan tinggi lahir mati karena kadar $\mathrm{Hb}$ ibu hamil tinggi namun tidak terdeteksi. Hal ini kemungkinan disebabkan oleh karena pemeriksaan $\mathrm{Hb}$ menggunakan metode sahli (Asam Hematin) yang akurasinya masih di bawah standar yaitu $\pm 10 \%$ dibanding dengan pemeriksaan $\mathrm{Hb}$ dengan metode talquist dengan akurasi $85 \%$ dan metode hemoCue sebagai standar baku emas (gold standard). ${ }^{31}$

\section{Hubungan kualitas antenatal care dengan kejadian lahir mati}

Kehamilan tanpa pengawasan antenatal akan berdampak buruk pada janin. Kehamilan adalah suatu proses reproduksi wanita yang perlu mendapatkan perawatan khusus agar dapat berlangsung dengan baik. Kehamilan berarti kehidupan bagi ibu maupun janin. ${ }^{4}$

Ditemukan hubungan signifikan antara ibu hamil yang ANC tidak berkualitas dengan kejadian lahir mati. Hasil penelitian ini menguatkan bahwa adanya managemen yang optimal termasuk adanya pengawasan yang ketat secara medis selama hamil menyebabkan resiko terjadinya bayi lahir mati pada masa perinatal dapat ditekan. ${ }^{25}$

Intervensi pada perawatan ibu hamil dapat menurunkan kematian perinatal hingga 75\%. ${ }^{12}$ Penurunan kematian perinatal di negara berkembang termasuk di Indonesia, akan sangat ditentukan oleh penatalaksanaan kesehatan ibu pada saat kehamilan. ${ }^{23}$

Hasil penelitian ini berbeda dengan Stephansson et al. yang menyimpulkan bahwa peningkatan bayi lahir mati di alami oleh para wanita yang berasal dari golongan sosial ekonomi yang rendah akibat terdapat perbedaan dalam hal perawatan secara medis terhadap janin dan ibunya bukan karena ibu selama hamil tidak memperoleh pelayanan kesehatan yang berkualitas bagi dirinya dan janinnya. ${ }^{26}$

Di Kota Ambon pelaksanaan ANC secara kuantitas baik, namun tidak terbukti. Hal ini 
ditemukan rata-rata hasil pelayanan ANC tidak secara konsisten didokumentasikan, sehingga ada kemungkinan ditemukan faktor risiko terhadap outcome kehamilan buruk yang perlu proaktif menggali penyebab untuk ditidaklanjuti, menjadi tidak terlaksana. Hal ini terbukti dalam penelitian ini bahwa, kelompok lahir mati sejak sebelum hamil sampai dengan melahirkan telah terpapar asap rokok, sehingga lahir mati tinggi walaupun kenyataan usia dan paritas lebih besar tidak berisiko.

Diasumsikan bahwa ibu yang sejak usia muda telah terpapar asap rokok lebih besar risiko lahir mati walaupun, selama hamil melakukan perawatan kehamilan secara teratur. Untuk mengurangi risiko terjadinya lahir mati, diperlukan kampanye anti rokok selama masa kehamilan, sebab setelah 20 menit berhenti merokok tekanan darah berangsur normal, detak jantung kembali normal, temperatur kembali ke kondisi seperti belum merokok. ${ }^{18,22}$ Delapan Jam berhenti merokok kadar karbon monoksida dalam darah menurun hingga berada dalam ambang normal.

\section{Hubungan umur dan paritas ibu hamil dengan kejadian lahir mati.}

Tidak ada hubungan yang bermakna antara umur, paritas dengan kejadian lahir mati. Hasil penelitian ini mendukung penelitian lain yang mengatakan bahwa kemungkinan umur dan paritas ibu saat hamil masih merupakan salah satu determinan lahir mati yang perlu dilakukan penelitian lanjutan. ${ }^{24}$ Berbeda dengan hasil penelitian Winbo et al. yang melaporkan bahwa paritas 1 dan 5 atau lebih akan meningkatkan resiko terjadinya berat bayi kecil untuk masa kehamilan, asfiksia dan bayi imatur. ${ }^{32}$ Namun kematian tinggi pada paritas pertama di usia ibu $<20$ tahun. Telah diketahui bahwa primipara mempunyai risiko lebih besar terhadap outcome bayi yang dilahirkan jika dibandingkan dengan paritas 2 sampai dengan pritas 4 . Hal ini berkaitan dengan kesiapan biologis ibu dan terkait juga dengan faktor-faktor lain seperti pengetahuan ibu dan gizi.

Umur ibu saat hamil sangat berpengaruh terhadap outcome bayi yang dilahirkan. ${ }^{16}$ Oleh karena faktor biologis, maka kehamilan usia muda akan menjadi beban terhadap sistem reproduksi yang sedang tumbuh. Sedangkan pada ibu usia 35 tahun lebih akan memberikan outcome yang juga kurang baik terhadap bayi yang dikandungnya. Hal ini disebabkan usia biologis jaringan reproduksi pada ibu menjadi kurang potensial lagi untuk mendukung pertumbuhan janin, disamping adanya faktor penyakit ibu.

Hasil penelitian tentang umur dan paritas ditemukan lebih besar tidak berisiko, namun lahir mati di Kota Ambon tinggi. Hal ini dapat disebabkan karena perempuan lebih besar terpapar asap rokok sejak sebelum hamil. Umur saat menikah di Kota Ambon terbanyak setelah 20 tahun (64\%) dan cakupan penggunaan kontrasepsi tinggi (69\% akseptor aktif) sehingga memungkinkan jumlah kelahiran rendah. ${ }^{7}$

\section{Hubungan pendidikan ibu hamil dengan kejadian lahir mati.}

Hubungan ibu hamil pendidikan rendah dengan kejadian lahir mati diperoleh adanya hubungan yang signifikan saat analisis bivariat, namun ketika dianalisis multivariat hasil menjadi tidak bermakna. Hasil penelitian ini mendukung penelitian di China yang meneliti upaya mencegah menjadi perokok pasif pada wanita hamil yang tidak merokok di Guangzhou. ${ }^{13}$ Hasilnya bermakna secara praktis tetapi tidak bermakna secara statistik. Dibuktikan melalui nilai $\mathrm{OR}=1,36 ; 95 \% \mathrm{Cl}=0,70-3,04$. Hal ini berarti, wanita dengan pendidikan dan pengetahuan yang tinggi 1,36 kali lebih dapat mencegah dan menghindari paparan asap tembakau di rumah maupun di tempat-tempat umum. 
Selanjutnya dikatakan bahwa responden dengan pendidikan tinggi bisa saja tidak diiringi dengan pengetahuan yang tinggi tentang bahaya asap rokok selama kehamilan. Demikian pula dengan responden yang pendidikan rendah. Pendidikan responden rendah diiringi dengan pengetahuan yang rendah akan bahaya asap rokok selama kehamilan, sehingga baik pada ibu berpendidikan tinggi maupun berpendidikan rendah tidak ada perbedaan, dan didapati pendidikan ibu tidak berhubungan dengan risiko lahir mati.

Pendidikan ibu adalah bagian paling mendasar dari karakteristikibu yang berhubungan dengan outcome kehamilan dan kelangsungan hidup bayi yang dilahirkan. ${ }^{10}$ Tingkat pendidikan ibu menjadi dasar terhadap pola pikir ibu perihal kehamilannya serta persiapan dan langkah-langkah yang mesti ditempuhnya. Ibu yang berpendidikan rendah, memiliki peluang yang lebih rendah terhadap kualitas bayi yang dikandungnya. Sedangkan Goldenberg et al. dalam kajiannya mengatakan bahwa meningkatnya bayi lahir mati bukan akibat dari wanita yang berasal dari golongan sosial ekonomi rendah khususnya mereka yang berpendidikan rendah, tetapi akibat dari terdapat perbedaan dalam hal perlakuan perawatan secara medis terhadap janin dan ibunya. ${ }^{8}$

Hal ini didukung oleh data ${ }^{2}$ yang menyatakan akses ibu hamil memeriksakan kehamilan sangat baik tetapi, mutunya perlu ditingkatkan. Dikatakan bahwa kurang dari satu di antara tiga wanita hamil diterangkan tentang tandatanda komplikasi kehamilan, diukur tinggi badan, diperiksa darahnya, dan diperiksa urinnya. Dikatakan bahwa, wanita yang pendidikan rendah cenderung kurang mendapat pelayanan pemeriksaan lengkap dibandingkan dengan wanita pendidikan tinggi. Pendidikan merupakan faktor yang mendukung kebutuhan ibu dalam pemanfaatan pelayanan kesehatan. ${ }^{29}$ Selanjutnya dikatakan bahwa, pendidikan dapat meningkatkan akses seseorang terhadap pelayanan kesehatan yaitu dengan meningkatkan akses wanita terhadap informasi, meningkatkan harga diri wanita dan meningkatkan kemampuan mereka dalam menyerap konsep-konsep kesehatan yang baru dan interaksi yang seimbang antara penyedia pelayanan dan klien. Hal ini didukung oleh data ${ }^{2}$ bahwa, ibu yang pendidikan rendah hanya $49 \%$ membahas tentang masalah yang berhubungan dengan kelahiran bayinya dibanding dengan ibu yang berpendidikan tinggi sebesar $85 \%$.

\section{DAFTAR PUSTAKA}

1. Aditama, T.Y. (2004) Sepuluh program penanggulangan rokok. Majalah Kedokteran Indonesia, 54 (7): 255-25.

2. Badan Pusat Statistik, Badan koordinasi keluarga berencana nasional, Departemen Kesehatan RI. (2003) Survey Demografi dan Kesehatan Indonesia 2002-2003. Calverton, Maryland: ORC Macro USA.

3. Dharma, A. \& Hamid. (2002) Karakteristik bayi berat lahir sangat rendah di RS Sanglah Denpasar. Buletin IImu Kesehatan Anak, VII(1): 3-10.

4. Dewi, S., Irma, S., Thontowi, D., 2005, Beberapa Faktor yang Mempengaruhi Kematian Bayi dan Maternal di Kabupaten Malang, Jurnal IImu Kesehatan Anak, vol 2 (2), 141-160.

5. Depkes RI. (2006) Pedoman pelaksanaan stimulasi, deteksi dan intervensi dini tumbuh kembang anak ditingkat pelayanan kesehatan dasar. Jakarta: Direktorat Jenderal Bina Kesehatan Masyarakat Direktorat Kesehatan Keluarga.

6. Depkes RI. (2006) Profil Kesehatan Indonesia tahun 2006. Jakarta: Depkes RI.

7. Dikes Kota Ambon. (2007) Profil kesehatan Kota Ambon. Ambon tahun 2007. Ambon.

8. Goldenberg, G. L., Kirby, R. \& Culhane, F. (2004) Stillbirth: a review. J Matern Fetal Neonatal Med, 16, 79-94.

9. Hegaard et al. (2006) The effect of environmental tambacco smoke during pregnancy on birth weight. EBSCO Vol.85 issue 6p 675-681, 7p, 3 charts.

10. Hellen, M.W. (1992) Maternal health antecedents of infant and early childhood mortality and morbidity. J Trop Pediatr, 38(1): 4-6. 
11. Kramer, M.S. (2002) The Epidemiology of adverse pregnancy outcome: an overview. J Nutr, 133(5 Suppl 2): 1592S-1596S.

12. Lawn, J., McCarthy, B.J., Rae, S. (2000) The healthy new born; a reference manual for program managers. Center for Diseases Control and Prevention.

13. Loke, A.Y., Lam, T.H., Pan, S.C.P,Li, S.Y, Gao, X.J., Song, Y.Y. (2000) Exposure to and Actions Against Passive Smoking in Non-Smoking Pregnant Woman in Guangzhou, China. Acta Obstetrica et Gynecologica Scandinavica. ISSN 0001-6349, pp. 79-947-952.

14. Mangoenprasodjo, S.A. \& Hidayati, N.S. (2005) Hidup sehat tanpa asap rokok. Yogyakarta: Pradipta Publishing.

15. Mary L. Blankson, MD, MPH, Robert L. Goldenberg, MD, Gary Cutter, PhD, and Suzanne P. Cliver Birmingham, Alabama. Maternal hematocritand pregnancy black-white difference outcome. J Natl Med Assoc. 1993;85:130-134.

16. Mishra, P.K., Thakur, S., Arvind, K. \& Tandon, S. (1993) Perinatal mortality in rural India with spacial reference to high risk pregnancies. J Trop Pediatr, 39 (1): 41-44.

17. Mishra, V., Retherford, R.D. \& Smith, K.R. (2005) Cooking smoke and tobacco smoke as risk factors for stillbirth. Int J Environ Health Res, 15(6): $397-$ 410.

18. Mohsin, M., Bauman, A. E. \& Jalaludin, B. (2005) The Influence of antenatal and maternal factors on stillbirths and neonatal deaths

19. Monintja, H.E. (2002) Kematian Perinatal. Dalam(penulis) IImu Kebidanan, Jakarta: Yatasan Bina Pustaka Sarwono Prawirohardjo, 734-737.

20. Norman, C.A. \& Haiton, D.M. (1990) Is carbon monocide a workplace teratogen? A review and evaluation of the literature. Ann Occupational Hygiene, 34 (4): 335-347. available from: http:// www.who.int (accessed, 21 Januari 2009).

21. Ojembarrena, A., Cano.F.J., Giron, V.A., Yep, C.G., Sanches, B.M. (2005) Birth Weight and Familial Smoking. Pubmed, 63 (2);116-9.
22. Oliviero (2008) Smokeout is reminder that quitting starts day at a time. The Atlanta JournalConstitution.

23. Pramaswari (2007) Kematian perinatal Indonesia dan faktor yang berhubungan tahun 1997-2003. Jurnal Kesehatan Masyarakat Nasional vol. 1, No 4 Februari 2007.

24. Shah, P. \& Ohlsson. A. (2002) Literatur Review of Low Birth Weight, Including Small for Gestational Age and Pterm Birth. Toranto Public Health. Toranto.

25. Smith, G.C.S. \& Fretts, R. (2007) Stillbirth. Lancet, 370, 1715-1725.

26. Stephansson, O., Dickman, P.W., Johansson, A. \& Cnattingius, S. (2000) stillbirth. JAMA, 284(20): 2611-2617.

27. Soetjiningsih. (2002) Tumbuh Kembang Anak, II. Jakarta: Buku Kedokteran EGC. Jakarta.

28. Syafei. (2007) Konsultan Hematologi Onkologi Medik Rumah Sakit Kanker Dharmais. Jakarta.

29. Thaddeus \& Maine. (1990) Prevention of Maternal Mortality Program, Center for Population and Family Health, New York, Columbia University, May. iv, $175 \mathrm{p}$.

30. Theresa, O., Scholl and Thomas Reilly. (2000) Anemia, iron and pregnancy outcome. J. Nutr. 130: 443S-447S.

31. Van den Broek, N.R., Ntonya, C. Mhango, E. \& S.A. White, S.A. (1999) Diagnosing anaemia in pregnancy in rural clinics: assessing the potential of the Haemoglobin Colour Scale. Bull World Health Organ, 77(1): 15-21.

32. Winbo, I., Serenius, F., Dahlquis, G. \& Kallen, B. (2001) Maternal risk factors for causes-specific stillbirth and neonatal death. Acta Obstet Gynecol Scand, 80, 235-244.

33. Wisborg, K., Kesmodel, U., Henriksen, T. B., Olsen, S. F. \& Secher, N. J. (2001) Exposure to tobacco smoke in utero and the risk of stillbirth and death in the first year of life. Am J Epidemiol, 154(4): 322327.

34. World Health Organization (2000) Making pregnancy safer report. Geneva. 